\title{
Effect of Competitive Strategies on Growth of Savings and Credit Cooperative Societies in Tharaka Nithi County, Kenya
}

\author{
Anderson Njue Njoka \\ Department of Business Administration, Chuka University, Nairobi, Kenya
}

Email address:

njuea@yahoo.com

To cite this article:

Anderson Njue Njoka. Effect of Competitive Strategies on Growth of Savings and Credit Cooperative Societies in Tharaka Nithi County, Kenya. European Business \& Management. Vol. 7, No. 2, 2021, pp. 24-41. doi: 10.11648/j.ebm.20210702.11

Received: February 15, 2021; Accepted: March 24, 2021; Published: April 26, 2021

\begin{abstract}
A savings and credit cooperative society (SACCO) is an association of persons who have come together with an aim of pooling their resources together for economic benefit. Kenyan SACCOs play a key role in wealth creation, poverty alleviation, and employment. Kenyan SACCOs have high growth potential but are bedeviled by challenges like strong competition from commercial banks, insufficient capital, slow rate of information technology adoption, inefficient loan pricing strategies and weak governance. The SACCO sector is growing at the rate of $20 \%$ per annum but has potential for further growth. This raises a question as to which strategies SACCOs are adopting to enhance growth. Previous researches did little to investigate effect of competitive strategies on growth of SACCOs despite the challenges dogging the sector hence this is a gap that needs to be filled. It is against this backdrop that this study sought to investigate the effect of competitive strategies on growth of SACCOs in Tharaka Nithi County, Kenya. The general objective of the study was to investigate the effect of competitive strategies on growth of SACCOs in Tharaka Nithi County, Kenya. The specific objectives were to determine the effect of market development, product development and cost leadership strategies on growth of SACCOs in Tharaka Nithi County, Kenya. The study adopted descriptive survey research design. The study location was Tharaka Nithi County, Kenya. The population of the study was the 10 SACCOs in Tharaka Nithi County. The sample size was census of the 52 managerial staff of the 10 SACCOs. Data was collected using structured questionnaires. Validity was ensured through use of experts who were the supervisors. Reliability was determined by the test-re-test method. Data analysis was facilitated by use of the statistical package for social sciences (SPSS) version 21. The results obtained from the study indicated that market development, product development and cost leadership strategies significantly influenced membership, loans issued and return on equity of the SACCOs at $5 \%$ significance level. These findings implied that the competitive strategies significantly influenced growth of SACCOs in Tharaka Nithi County, Kenya.
\end{abstract}

Keywords: Competitive Strategies, Growth of SACCOs, Market Development Strategy, Product Development Strategy, Cost Leadership Strategy

\section{Introduction}

\subsection{Background to the Study}

The Kenyan Vision 2030's economic pillar envisages a growing, vibrant and globally competitive financial sector [21]. SACCOs are instrumental in the achievement of this vision [32]. Kenyan SACCO movement is faced with many challenges and threats emanating from weak governance, competition from commercial banks and microfinance institutions [21]. SACCOs should adopt appropriate strategies to address these challenges
[50]. A strategy is the direction of an organization over the longer term, which matches its resources to its changing environment [24]. A competitive strategy is a formula on how the firm will compete, what its goals will be and the policies necessary to achieve these goals [7]. A competitive strategy entails the actions that a firm takes to attract customers, survive competitive pressure and enhance its market position [24. Competitive strategy has to do with what a firm is doing in order to attain a sustainable competitive advantage [29]. Firms react to turbulence in the business environment by crafting competitive moves vital for survival and growth [1]. This 
study conceptualized competitive strategy as an approach that a firm adopts to outdo performance of its rivals.

When a firm has grown, it has increased in size, expanded, made more profits and is bigger in terms of operations than where it began [50]. Growth refers to increase in basic indicators to performance such as total sales, production volume and use of raw materials [29]. Business growth is all about ensuring that shareholders of the firm get value for their investment [33]. The researcher further accentuates that growth of a firm involves three areas of outcomes namely, financial performance (profits, return on assets and return on investment); product market performance (sales \& market share); and shareholder return. This study conceptualized SACCO growth as increase in membership, loans issued and return on equity.

Worldwide, there are 55,952 cooperatives with a total membership of 200,243,841 and savings of 1 trillion US dollars [53]. Ireland has a strong SACCO movement with 1.6 million people (44\% of the population) in membership [5]. In UK, SACCOs are outperforming the banks. They are considered by customers to be more trustworthy than their competitors [55]. Marvin further asserts that in USA, there are over 18,000 well established SACCOs serving 70 million members and with more than $\$ 300$ billion in assets. SACCOs in Malaysia are faced with challenges such as inadequate capital, poor governance, poor finance performance and mismanagement [44]. SACCOs in India are dogged by problems such as inadequate capital, inadequate managerial skill, corruption, and fraud [46].

Over 60 million people depend on SACCOs in Africa [25]. Cooperative movement in Nigeria is not very popular despite its old age [10]. This is because SACCOs are seen to be associations meant for very low income earners, farmers and small traders hence many SACCOs face growth challenges. Contrary to this, a study by on challenges facing SACCOs in Ethiopia revealed the SACCOs have witnessed growth in terms of membership and capital and have growth rate of $28 \%$ per year [20]. SACCOs in Uganda are facing corporate governance challenges which involves; existence of volunteer board of directors and limited individual influence [47]. SACCOs across sub-Saharan Africa have a potential of realizing 31\% growth rate per annum [20].

Kenya has 6,750 registered SACCOs with a membership of over 3 million [35]. Kenyan SACCOs play a vital role in wealth creation, poverty alleviation, employment, and development of the society. Just like other businesses, SACCOs face challenges in their attempt to survive and grow [25]. Competition is very stiff in the financial service industry because commercial banks and other financial institutions target salaried employees who are SACCO members hence SACCOs have lost a significant number of members to commercial banks and other financial institutions [45]. This competitive pressure has led to decline in performance of SACCOs hence growth and if this trend continues, SACCOs will be adversely affected. Many SACCO members opt to borrow loans from commercial banks because obtaining loans from SACCOs can be limited by pro rata requirements and if nothing is done to reverse this trend, a number of SACCOs may collapse due to poor growth. Cooperative movement is the vital vehicle for wealth creation among its members but recent developments show that something is wrong [37]. Ngugi further observes that many SACCOs experience problems such as poor leadership, poor management, and weak capital base which adversely affect their growth [37].

A study by Uluma indicates that the Kenyan SACCO sector growth rate is $20 \%$ per year [50]. However, the sector has high growth potential which can be exploited by adopting appropriate growth strategies so that SACCOSs can serve the un-banked segment of the population and deepen financial access in the country. Mumanyi reinforces this position by stating that SACCOs have high growth potential which is inhibited by challenges facing the sector namely: competition from Kenyan commercial banks, weak capital base, slow rate of information technology adoption, inefficient loan pricing strategies and weak governance [30]. While it must be appreciated that strategic interventions are a prerequisite for survival and growth of Kenyan SACCOs, the effect of competitive strategies on growth of SACCOs should be identified to ensure that SACCOs exploit their full growth potential [29].

\subsection{Statement of the Problem}

The Kenyan Vision 2030's economic pillar envisages a growing, vibrant and globally competitive financial sector. The SACCOs are instrumental in the achievement the vision. Worldwide, there are 55,952 SACCOs with a total membership of 200,243,841 [53]. Kenya has 6,750 registered SACCOs with a membership of over 3 million [35]. Kenyan SACCOs play a key role in wealth creation, poverty alleviation, employment [37]. Kenyan SACCOs have high growth potential but are bedeviled by challenges such as strong competition from commercial banks, insufficient capital base, slow adoption of information technology, poor loan pricing strategies and weak governance. SACCOs across sub-Saharan Africa have a potential of realizing $31 \%$ growth rate per annum [44]. SACCOs in Ethiopia have witnessed growth in terms of membership and capital and have growth rate of $28 \%$ per year [20]. Despite the high growth potential, Kenya's SACCO sector is growth rate is $20 \%$ per year [50]. This raises questions as to which strategies SACCOs are adopting to survive the stiff competition and attain at least $31 \%$ growth rate per year as recommended. Previous researches did little to assess the impact of competitive strategies on SACCOs growth despite their high growth potential hence there is gap that needs to be filled. Specifically, the study intended to fill the gap on the effect of market development, product development and cost leadership strategies on growth of SACCOs. It is against this backdrop that this study sought to investigate the effect of competitive strategies on growth of SACCOs in Tharaka Nithi County, Kenya.

\subsection{General Objective of the Study}

The general objective of the study was to investigate the 
effect of competitive strategies on growth of SACCOs in Tharaka Nithi County, Kenya.

\subsection{Specific Objectives}

The study was guided by the following specific objectives.

1. To determine the effect of market development strategy on growth of SACCOs in Tharaka Nithi County, Kenya.

2. To establish the effect of product development strategy on growth of SACCOs in Tharaka Nithi County, Kenya.

3. To determine the effect of cost leadership strategy on growth of SACCOs in Tharaka Nithi County, Kenya.

\subsection{Hypotheses}

The following were the study hypotheses;

$\mathrm{H}_{\mathrm{O} 1}$ : There is no significant relationship between market development strategy and growth of SACCOs in Tharaka Nithi County, Kenya.

$\mathrm{H}_{\mathrm{O} 2}$ : There is no significant relationship between product development strategy and growth of SACCOs in Tharaka Nithi County, Kenya.

$\mathrm{H}_{\mathrm{O} 3}$ : There is no significant relationship between cost leadership strategy and growth of SACCOs in Tharaka Nithi County, Kenya.

\subsection{Significance of the Study}

The findings of the study would inform the government and community on strategic interventions SACCOs adopts to foster growth. This study would also be of value to the management of SACCOs in Kenya as a reference point for strategies being put in place to achieve growth both in the present and in the future. The study would also be important to financial institutions which operate in the same environments as SACCOs.

\subsection{Scope of the Study}

The study investigated the effect of competitive strategies on growth of SACCOs in Tharaka Nithi County, Kenya with specific focus on effect of market development, product development and cost leadership strategies on the increase in membership, loans issued and return on equity. These variables provided a background against which the objectives of the study were met. The sample size for this study was census of all the 52 managerial staff of the 10 SACCOs in Tharaka Nithi County, Kenya

\subsection{Limitation of the Study}

One of the limitations of the study was that most of the respondents were not willing to fill the questionnaire during data collection. This was due to the sensitive nature of the information being sought which they deemed confidential. This was however overcome by assuring them that the information was meant for academic purposes only.

\subsection{Assumptions of the Study}

The study was based on the assumption that the respondents were willing to respond to questions appropriately.

\subsection{Operational Definition of Terms}

Table 1. Operational Definition of Terms.

\begin{tabular}{ll}
\hline Strategy & $\begin{array}{l}\text { A strategy is the direction of an organization over the longer term, which matches its resources to its changing } \\
\text { environment, and in particular, to its markets, customers and clients to meet stakeholder expectations. } \\
\text { Refers to increase in membership, loans issued and return on equity } \\
\text { Growth of SACCOs }\end{array}$ \\
$\begin{array}{l}\text { Firm } \\
\text { Andustry }\end{array}$ & Group of firms involved in production of a particular good or service. \\
Competitive strategy & Approach that a firm uses to outdo performance of its rivals. \\
Market development strategy & Seeking new customers by targeting non-buying customers in currently targeted segments and new customers in new \\
Product development strategy & Segments. \\
Cost leadership strategy & An application of the lowest cost of operation in an industry in order to gain advantage over competitors.
\end{tabular}

\section{Literature Review}

The chapter looked at theoretical framework and reviewed literature on concept of competitive strategy and growth. It also reviewed literature on market development strategy and growth, product development strategy and growth, cost leadership strategy and growth and finally looked at conceptual frame work.

\subsection{Theoretical Framework}

This study was guided by resource based view theory (RBV). RBV is a theory that explains how firms gain sustainable competitive edge through deployment of resources and capabilities. The theory emphasizes that to understand how competitive advantage is determined within firms, one has to consider company's internal organization, its resources and capabilities. The theory originated from the work of Penrose [41]. However, the view was formerly given by Wernerfelt. According to Wernerfelt, instead of emphasizing market entry barriers as a means of attaining competitive advantage, RBV stressed 'resource position barriers' as a strategy to increase profits. Resources can be used to create entry barriers hence increase performance at the industry level. Wernerfelt alludes that a firm is made up of unique resources, competencies and capabilities that provide the basis for its strategy and the major source of its returns. The researcher further points out that crafting and implementation of strategies and exploitation of opportunities can be done using 
unique resources.

Wernerfelt tries to underscore the importance of looking at a firm as a collection of evolving resources and capabilities that are managed dynamically in pursuit of above- average returns [41]. Wernerfelt holds that a firm can attain sustainable competitive advantage through resources that are valuable, rare among competitors, inimitable and nonsubstitutable. These resources are tangible and intangible assets such as firm's management skills, its organizational processes and routine and the information and knowledge under its control. RBV asserts that competitiveness may be attained by offering superior value to clients and efforts should be made to leverage the firm's resources and capabilities to create value for customers and competitive advantages for the firm [4]. RBV focuses on strategic identification and use of resources by a firm to develop a sustainable competitive advantage. RBV accentuates the need for a fit between the external competitive environment and its internal resources and capabilities. Wernerfelt notes that resources of a firm may be put into three categories namely: physical capital, human capital and organizational capital. A capability is a capacity for a set of resources to perform a stretch task of an activity. Therefore, firm's performance and growth is driven by its unique resources and capabilities rather than by an industry's structural characteristics.

$\mathrm{RBV}$ is one of the most commonly known strategic management theories. One of the limitations of RBV is that the theory does not explain how firms can determine whether resources and capabilities at their disposal are valuable, rare, inimitable and non-substitutable enough to enable them achieve sustainable competitive advantage. RBV also assumes that firm's resources and capabilities are the only factors that influence competitiveness and growth whereas other factors like economic cycles and government policies also influence firm's competitiveness and growth. The theory can be used to explain how SACCOs gain competitiveness by offering superior value to customers through innovatively deploying resources that are valuable, rare among competitors, inimitable and non-substitutable. RBV can also be used to explain how SACCOs can focus on the strategic identification of unique resources and capabilities at their disposal and craft effective competitive strategies so as to attain growth.

\subsection{The Concept of Competitive Strategy}

According to Parthasarthy, a strategy is a series of actions and decisions made by managers in order to outdo their rivals [48]. A strategy is an organization's long term direction matching its resources to the dynamic environment [1]. Organizations develop competitive strategies in response to environmental turbulence which are vital for organizational survival and growth [42]. A strategy assists a firm to interact with the environment. Mwaura further states that a competitive strategy is the strategy that a firm adopts so as to have an advantage over the others in the industry [34]. The researcher further alludes that competitive strategy entails actions that a firm is taking in an attempt to attain enduring competitive advantage. Ngigi did a research on strategies which SACCOs can use to gain competitive advantage in Kenya [36]. This study dwelled on the types of strategies which SACCOs can adopt to gain competitive advantage. However, the study did not focus on impact of these strategies on growth of SACCOs and yet SACCOs are struggling to stay afloat due to ferocious competition.

There are several levels of strategy. The highest level is corporate strategy. This level shapes corporate goals, mission, values, and culture [17]. Under corporate strategy there are functional/business level strategies which include market development, new product development, human resource, financial, legal and information and technology management strategies. They focus on short and medium term plans and are limited to the domain of each department's functional responsibility. Every department contributes to the achievement of the company's overall goals. Operational strategy is the lowest level of strategy. It has limited scope, concerned mainly with day-to-day operating plans including scheduling requirements. Business level strategies, in turn, inform operational level strategies and business level strategies are informed by corporate level strategies. Kaara maintains that effective strategic responses are powerful weapons for a company seeking to gain a long-term competitive advantage hence growth [18]. The researcher further observes that the strategic responses that SACCOs can adopt include new product development and market development. This study conceptualized competitive strategy as an approach adopted by a firm to outdo its rivals.

\subsection{The Concept of Growth}

A study by Uluma indicates that when a firm has grown, it has increased in size, expanded, made more profits and bigger in terms of operations than where it began [50]. In a study on growth strategies adopted by banks, Mosiria reinforces this position; that growth refers to increase in basic indicators to performance such as total sales, production volume and use of raw materials [29]. A study by Murithi asserts that business growth is all about ensuring that shareholders of the firm get value for their investment [33]. The researcher further accentuates that growth of a firm involves three areas of firm outcomes namely, financial performance (profits, return on assets and return on investment); product market performance (sales \& market share); and shareholder return. In his study, OLunja observes that growth of an organization can provide a number of benefits, including increased efficiencies from economies of scale, increased control, increased profit, and increased capacity to withstand market dynamics [40]. Olunja further argues that between 1989 and 1992, Kenyan government was forced by international monetary fund and world bank to introduce labialization which opened the economy hence all the firms including SACCOs began to feel the impact of globalization through sales decline, increased competition, changing buyer tastes and slow market and share growth. The firms responded by adopting various strategies such as strategic planning, performance contracting and market 
development so as to stay afloat. A research done in Sweden by Wikund on determinants of growth in SACCOs found that employee-wellbeing is the single most important aspect towards growth of a firm [54]. Ruttoh did a study on factors impacting growth of cooperative societies in Nandi central district [45]. The study found that a number of SACCOs experience huge transaction costs as a result of inefficiencies in their operations which adversely affect their growth. SACCO growth in this study was conceptualized as increase in membership, loans issued and return on equity.

\subsection{Empirical Literature on Competitive Strategies}

This section covers market development strategy and growth of SACCOs, Product development strategy and growth of SACCOs and cost leadership strategy and growth of SACCOs.

\subsubsection{Market Development Strategy and Growth of SACCOS}

Investigating the mediating effects of firm's competitive strategy in the market orientation-performance relationship in China, Ding found that market development strategies enhance performance, competitiveness hence growth of a firm [9]. The study further found out that innovation is the most critical factor in maximizing the company's value in the emerging market. Although the study provided interesting insights into the understanding of market development strategy-performance relationship, it did not examine potential impacts of environment on the market development strategy-performance relationship. This strategy entails moving into new market segments or moving into new geographical segments. In market development strategy, a firm targets new markets with existing products and it strives to acquire customers by offering its new products to market segments which were not its previous customers [4].

To implement a market development strategy, an organization focuses on these four groups: existing customers, non-buying in the current segments, competitor's customers, and new segments. The strategy entails exploration of new market segments, new uses for the firm's product, or new geographical areas in order to woo new customers with an aim of increasing the market, broaden customer base and eventually sell more products [26]. McCann's study further indicates that firms adopting this strategy use approaches such as opening additional geographical markets and attracting other market segments. Regional expansion, national expansion, and foreign expansion are all examples of geographical expansion. To increase market size, an organization has first to identify the market segments that are currently being served and convince current customers to buy new products they are not purchasing. Once this is done, the organization should move on and identify rival companies' clients and offer ideas to entice them, like discounts and promotions. In his study, Mwaura states that market development strategy involves marketing present products, often with minor modifications, to customers in related market areas by adding channels of distribution or by changing the content of advertising or promotion [34]. The researcher further points out that firms establishing branch offices in new countries, states or cities, are engaging in market development strategy.

Mbithi describes market growth strategy as the process of taking existing goods and discovering new opportunities by expanding previously untapped market segments, developing new marketing and distribution platforms, and expanding into new geographic markets [28]. Mbithi further asserts that by focusing on one, underserved consumer segment and converting non-users to users of the company's products, a market development strategy may improve efficiency and therefore growth. Two, by spreading into new geographic regions and taking either competitor market share or offering the product where it is entirely inaccessible or a substitute product is available. The researcher further states that in almost every field of the economy, there is an undeniable need to implement a business growth strategy to combat local and global rivalry. The findings of Mbithi's study were that, developing new market segments or expanding into new geographical areas increases sales volume and turnover hence growth [28]. According to Mbithi's study, expanding into new market segments, which includes capturing customers who have never used the product before and expanding into new geographic areas, will increase a company's sales volume by 5.6 percent. The study also verified that opening up more distribution channels through agencies and promotions has proved to be the current approach in acquiring new market regions without necessarily opening company outlets.

In his study on market and product development strategies used in response environmental changes faced by SACCOs in Nyeri County, Kaara [18] observes that the success of a company's growth strategy is determined by whether it sells new or existing goods in new or existing markets. Kaara found that SACCOs in Nyeri act to the volatile environment's challenges by implementing business and product development strategies that include finding new market segments, incorporating product functionality, and improving existing products. The researcher further recommends that SACCOs need to adopt diversification strategies in order to increase their market share. A study by Murunga [31] states that pursuing a market development strategy depends on the nature of organization's resources and core competencies. The researcher further points out that this strategy aims at meeting competition, securing sales, gaining market share, increasing profits and hence growth. In his study, Mumanyi [30] observed that due to fierce competition in the financial services industry, SACCOs should create marketing strategies and implement new high-quality goods and services so that members can profit from cooperative interest rates. The researcher further recommends that SACCOs should increase access to market channels, market their products and open their common bond to increase membership.

In his study on adoption of marketing concept and growth of SACCOs in Kenya, Olunja notes that for a firm to reach 
different target markets, the marketing should be proactive and evolve as the market evolve [40]. The researcher further states that market development strategy is crucial to firm's growth because it increases firm's profits and helps to achieve its strategic goals. Olunja contend that firms seeking growth use strategies such as market development, product development, joint venture, divestment of older technology or products and external financing. The study further alludes that firms can acquire secure significant growth by tapping new markets. The researcher found that for market development strategy to be effective among SACCOs in Kenya, there should be a continuous monitoring of competitors and scientific analysis of factors influencing their market development strategies. Market development strategy creates additional demand for a firm's product/service especially where competition has not fully developed and this can spur phenomenal growth for the firm. While most profit driven firms have adopted market development strategy, the Kenyan SACCOs are yet to fully embrace it. The liberalization of the financial sector in 2006 has created an environment in which survival of SACCOs depends on their ability to effectively implement a market development strategy. According to Olunja there is a major relationship between market development strategy and SACCO growth in Kenya [40]. According to Uluma, SACCOs can create new markets and opportunities by adopting new technologies. The researcher accentuates that firms that does not keep up with technological changes may miss market opportunities [50].

Organizations must identify the needs, desires, and preferences of the target market and provide satisfactions more efficiently and effectively than rivals as part of their market development strategy [50]. Firms that have adopted this strategy tend to have high performances hence growth. According to McDonald, selling more of a firm's current products to the current customers is the least risky growth strategy for any firm. However, for a firm to move its current products to an adjacent market there is need for a market development strategy [27].

The fit between a company's market growth strategy and its business model was investigated by Zott [56]. According to the findings, a novelty-centered business model combined with market development strategies that emphasize differentiation, cost leadership, or early market entry strategy can improve firm efficiency and growth. According to the study, a market growth approach and a business model are complementary rather than substitutive. However, the study didn't go into detail about how business models evolve, especially how they interact with the firm's market growth strategy. A firm pursuing market development strategy should also focus on untapped market segments. These are people who are not buying a product from either your firm or your competitors. Managers take steps including targeting promotions, opening sales offices, and forming partnerships to put a business growth plan into effect. Market development strategy aims at expanding the market so that the firm is in a position to grow [42]. Olunja found that that adopting a market development strategy would enable SACOs to understand their customers and enhance the growth [40]. This study conceptualized market development strategy as seeking new customers by targeting non-buying customers in currently targeted segments and new customers in new segments

\subsubsection{Product Development Strategy and Growth of SACCOs}

A business that rejects new and better ways of doing things will inevitably lose customers to a rival who has discovered a better way [16]. A study by Mwaura [34] asserts that product development strategy entails updating existing goods or new products are produced that can be sold to current customers. In a study on SACCOs services' terms and member's economic development in Rwanda, Tumwine [49] noted that SACCOs should understand the needs and interests, priorities of existing and potential clients and create a variety of appropriate products to enhance their performance and growth. This assertion is supported by a study by Okibo [39] which states that SACCOs should offer wide range of products directed to particular clients. Customers can choose between instantly available liquidity options, semi-liquid accounts, and time deposits with higher interest rates as a result of this.

According to Rutto [25], product development in SACCOs can be illustrated, for example, by the frequent introduction of new types of loans based on circumstances, the frequent reduction of loan processing and distribution time to borrowers, and the frequent changing of loan conditions. In a study on market and product development strategies used in response to environmental changes faced by SACCOs in Nyeri County, Kaara [18] notes that firms seeking growth should offer members products/services customized to their tastes and preferences. In response to the environmental problems that SACCOs face, the researcher suggests that they concentrate on product growth techniques such as product refining, creating new products, and extending product lines. This observation was further supported by Ngugi [37] who argues that SACCOs seeking to expand should gain a better understanding of their current and future customers' financial needs so that they can adapt and match goods and distribution methodologies to meet those needs. However, Kenyan SACCOs are grappling with the task of developing effective financial products and distribution mechanisms that reflect this fact. The study further states that in Kenya, the majority of SACCOs provide homogeneous products to their various clients. SACCOs need to tailor loan sizes to their clients' needs, develop new loan forms such as individual loans in addition to group-guaranteed loans, and provide a diverse range of products and services beyond credit. This will enhance outreach and loyalty among existing clients.

A study by Mumanyi [30] recommends that SACCOs should diversify their products for a greater future. In a study on adoption of marketing concept and growth of SACCOs in Kenya, Olunja [40] contend that customer preferences and 
attitudes keep evolving and require managers to adopt rapidly through modifying or creation of new products. The researcher further alludes that firms should supply products to suit new consumer tastes and that market research should be used to gauge consumer desires after which products should be developed attuned to the revealed information. A firm should strive to outperform its competitors by providing better products, better quality and better prices. Olunja further asserts that firms seeking growth use strategies such as market development, product development, joint venture, divestment of older technology or products and external financing. The findings of Olunja's [40] study were that market development strategy is instrumental to the growth of SACCOs and that the key way of meeting customers' needs is through product development strategy, offering a wide range of services, charging affordable interest rates on loans and identifying customer's needs regularly. The study further found that for SACCOs to achieve overall growth, they should improve their product offerings so as to attract new members and meet needs of existing members. Quality of services offered by SACCOs should be standardized, products must be rebranded, more services should be added and should also diversify their products and services as much as possible. Hansen [11] affirms this by noting that product development is the linchpin of most firms seeking growth.

Product development is important to a firm seeking growth and that a growing firm usually develops new products for new customers as dictated by the market conditions. A study by Olunja [40] found that development of market driven products is critical for survival and growth of SACCOs. Uluma [50] did a study on growth determinants of savings and credit cooperatives in Dagoret district. The researcher noted that due to increased competition, SACCOs should continually improve their products while maintaining competitive prices so as to achieve growth. The researcher further says that improved service may entail increasing the number of goods and services available to members while improving delivery of existing services. New credit products such as microfinance loans should be offered. Uluma further observes that SACCOs should offer diversified range of savings, credit and other financial products so as to remain competitive [50]. The findings showed that most SACCOs have significantly increased their savings base by diversifying their client base and membership. The findings also revealed that SACCOs' sustainability and growth are dictated by the types of products they offer and how special they are in contrast to other similar suppliers of the same product. SACCOs introduce new products as members' demand change to achieve growth and member retention. New credit items, such as microfinance loans, instant loans, and long-term loans, should be offered, according to Uluma [50]. A study by Kaara [18] maintains that effective strategic responses are powerful tools for a company seeking to gain a long-term competitive advantage and thereby expanding. The researcher further observes that the strategic responses that SACCOs can adopt include new product development and market development. The researcher further opines that
SACCOs seeking growth should offer members products customized to their tastes and requirements. The findings of his study were that SACCOs in Nyeri respond to challenges in the volatile environment by adopting market and product development strategies which entails targeting new market segments, adding product features and product refinement. The researcher further recommends that SACCOs need to adopt diversification strategies in order to increase their market share.

The strength in which consumers pursue variety is a stumbling block to customer retention. In a study on effects of new product development on customers' attraction by SACCOs in Baringo county, Kipkosgei [22] opines that the only constant in today's business world is change and for an organization to succeed, it should continuously align its business strategies, business operations, product line and their organizational culture to the needs and demands of the ever changing environment. The findings of the study were that new product developments greatly influence customer attraction by SACCOs. $35.9 \%$ of the respondents believe that their SACCOs develop new products based on customer needs. The research further found that majority of customers are dissatisfied with their SACCOs' product development policies because they do not represent their needs and desires. Kipkosgei recommended that customers' demographic surveys should be performed by SACCOs in order to define consumer preferences and expectations, enabling them to develop demand-driven goods and services that are versatile, responsive to the needs of customers, and within their capacity to repay [22]. He further recommends that SACCO management should perform a detailed market survey to identify current and future competitor product offerings. This will assist the SACCO management in recognizing potential challenges to its established customer base and, as a result, explore ways to outwit the competition. A study by Dahan [8] on new product development stated that successful new product development (NDP) is a critical cornerstone of firm's success. He further asserts that many businesses will benefit financially from effective new product introductions, which will help them overcome the declining growth and profitability of existing products. Dahan further notes that many new products fail, and there are plenty of costly examples in the new product creation landscape [8]. The researcher further adds that according to different studies, 3035 percent of new products introduced to the market fail. A 1990 study sponsored by the marketing science institute found that $25 \%$ of the successful firms' current sales were delivered from new product introduced in the last preceding three years. New product creation can also provide substantial economies of scale for the company, resulting in increased growth [12]. For there to be successful product development, there should be keen attention to competitors and customer needs now and in the future. This study conceptualized product development strategy as creation of new products or modifying existing products and offering those products to current or new markets. 


\subsubsection{Cost Leadership Strategy and Growth of SACCOs}

Cost leadership strategy refer to a set of actions taken to produce goods or services at the lowest cost relative to that of competitors in order to achieve high profits hence growth [19]. Kachaner, [19] further argues that low cost firms excel at cost reductions and efficiencies. This assertion is supported Pearce \& Robinson [42] who argues that cost minimization determines the firm's profit and it enhances competitiveness hence growth. Many firms worldwide build and promote their market power through cost leadership in the global price rivalry. Process innovation and economies of scale is the key to achieving cost leadership. When firms who have cost advantage cut the price, many organizations which rely on technology-imitation to enter into market are in "prisoner's dilemma". They have no choice but to cut down their price. Studies at Islamic Azad University in Iran by Hamid [14] indicated that experience, investment in manufacturing facilities, conservation, and close management of net operating costs are all part of the cost leadership strategy. As opposed to alternatives, a low-cost position typically puts a company ahead of its rivals in the industry. The findings of Hamid's study showed that cost leadership strategy has a positive and important relationship with a company's rate of return on assets and therefore growth, because if a company can use cost leadership strategy, revenue growth is expected to increase. A study by Habimana [13] in Rwanda indicated that competitive advantage is the cornerstone of profitability and sustainability of many firms in the financial sector nowadays. The researcher noted that there is ferocious competition in the financial sector of Rwanda and many commercial banks don't pay attention to cost leadership strategy and the consequence is that some banks are obliged to stop their operations or simply collapse. The findings of Habimana's study were that there was no relationship between cost leadership strategy and commercial banks in (in terms of growth of assets) because some banks under study had low level of cost and at the same time low level growth of assets while others had low level costs and a high level growth of assets.

Cost leadership is achieved by increasing profits by reducing costs and gaining a larger share of the market by charging lower prices [19]. To realize low cost leadership, a firm should identify areas where to implement cost reduction like production, marketing and research. Mwaura [34] states that economies of scale, the introduction of cost-cutting technologies, the elimination of overhead and operating costs, and preferential access to raw materials are all ways to achieve cost leadership. Cost leadership strategy is a means used by firms to achieve lower costs than their rivals by improving their process efficiency, accessing low cost raw materials and inputs, outsourcing, cutting down overall cost of operation and avoiding some costs all together. Low cost leaders depend on unique capabilities like securing suppliers of scarce raw materials, having a dominant market share or having high degree of capitalization. In a study on factors influencing growth of cooperative societies in Nandi central district, Ruttoh, [45] indicated that many SACCOs experience huge transaction costs as a result of inefficiencies in their operations which directly affect their growth. The researcher further states that lack of trained board of directors, poor governance, political interference, slow decision making process and government policies are the key factors inhibiting growth of credit cooperatives in Kenya.

A study by Olunja [40] concluded that to increase their growth and financial levels, SACCOs should apply technology in their day to day activities and hence reduce costs by providing reliable, intuitive online self-service options to their customers. Those already automated should embrace modern technology. The old and outdated computers and systems should be done away with and instead replace them with new versions for efficiency. Olunja's conclusion concurs with Uluma's [50] assertion who stated that SACCOs should adopt new technology so as to cut cost, grow and remain competitive. Uluma further noted that information communication technology (ICT) in SACCOs can reduce transaction costs, improved access to timely and usable knowledge and generally improve communication with the markets [50]. The researcher alludes that ICT is an essential tool for efficient operations and SACCOs should adopt this technology. Uluma adds that to save on costs, SACCOs should acquire compatible computer software, link up with private ATM service providers e.g. Pesa point and cooperative bank ATM and lastly link with other telecoms with countrywide network.

A study by Nyamweya [38] indicated that a company must operate at a lower cost than its competitors in order to deliver the lowest price while still maintaining profitability and a high return on investment. The researcher further indicates that minimization of direct and indirect operational costs are key to attaining low cost advantage. The findings of Nyamweya's study were that LPGCSs' success and development was influenced by their cost leadership strategy. He states that these firms gain cost leadership by minimizing procurement cost, operational cost and labor. A study by Mosiria [29] found out that there is strong and significant relationship between three growth strategies namely, market development, innovation and product development and the performance and growth of banks in Kenya. A study by Kaara [18] states cost leadership can be achieved through improving process efficiencies, gaining access to outsourcing products, making optimum outsourcing, vertical integration decisions, or completely eliminating certain costs. Outsourcing takes advantage of the economies of scale, experience, and scalability of foreign service providers, allowing buyers to focus on their core sector. Outsourcing is the most successful strategy for achieving higher return on investment and thus growth, according to savvy managers. Low cost firms are characterized by product simplicity, lower operating costs, specific positioning, enabling them to offer lower prices to their customers. Low prices offered by low cost firms attract new customers which lead to growth of these firms. A study by Ngigi [36] asserts that the danger with this cost leadership strategy is that competitors may leapfrog production capabilities and technology hence doing away with competitive advantage acquired from cost 
leadership. Before pursuing cost leadership, a company should be certain that it can attain and retain the top position. Mwaura [34] observes any practice in which a company does not have a cost advantage should be stopped, and operations should be outsourced to other organizations with a cost advantage. Mass manufacturing, mass distribution, economies of scale, technology, product design, input cost, capacity utilization of resources, and access to raw materials are all areas where a company can achieve cost leadership. Economies of scale, production designs, process advances, reducing manufacturing time and expense, and reengineering activities all lead to lower costs. Controlling production costs, increasing capacity usage, controlling materials supply or product delivery, and lowering research and development (R\&D) and advertisement costs are all ways to gain a cost advantage. Firms with a long-term cost advantage over rivals use the cost advantage to either undercut competitors and gain significant market share at their expense, or to achieve a higher profit margin at the going rate. Firms pursuing a low-cost advantage should preserve productivity in

\section{Competitive Strategies}

all operations in order to efficiently monitor any expense and identify new cost-cutting opportunities. This study conceptualized cost leadership strategy as an application of the lowest cost of operation in an industry in order to gain advantage over competitors. Previous researches did little to assess effect of competitive strategies on growth of SACCOs despite the fact that the sector is dogged by serious challenges which hinder growth hence there is gap that needs to be filled. More specifically, the study intended to fill the gap on the effect of market development, product development and cost leadership strategy on growth of SACCOs. It is against this backdrop that this study sought to investigate the effect of competitive strategies on growth of SACCOs in Tharaka Nithi County, Kenya.

\subsection{Conceptual Framework}

The conceptual framework of this study shows the relationship between independent and dependent variables.

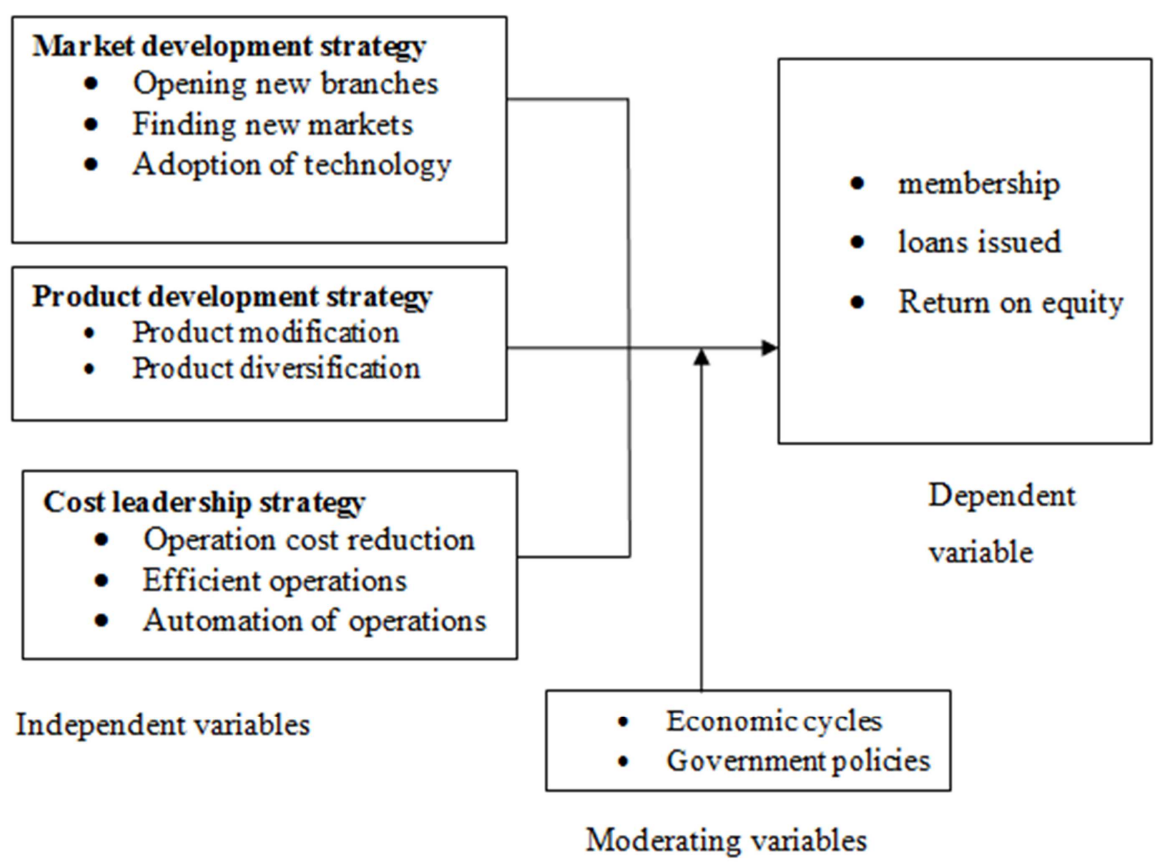

Figure 1. Relationship Between Competitive Strategies and Growth.

The relationship between variables is represented in Figure 1 which indicates that the independent variables are the competitive strategies and dependent variable is growth. Competitive strategies have an effect on growth of SACCOs. Competitive strategies are characterized as market development strategy, product development strategy, cost leadership strategy, and growth as increase in membership, loans issued and return on equity. The study further conceptualized market development strategy as opening new branches, finding new markets for existing products and adoption of technology for service delivery. Product development strategy as product modification and product diversification. Cost leadership strategy as operation cost reduction, efficient operations and automation of operations. The framework holds that if there are proper competitive strategies based on effective market development strategy, continuous product development strategy and cost leadership strategy, then SACCOs will have increase in membership, loans issued and return on equity. Effective strategies should lead to growth of SACCOs. However, the effectiveness of the above strategies could be indirectly affected by some moderating variables such as economic cycles and government policies

\subsection{Operationalization of Variables}

The variables were operationalized as follows in the study. 
Table 2. Operationalization of Variables.

\begin{tabular}{lll}
\hline Variable & Definition & Measurement \\
\hline \multirow{2}{*}{ Market development strategy } & $\begin{array}{l}\text { Seeking new customers by targeting non-buying customers in currently targeted } \\
\text { segments and new customers in new segments }\end{array}$ & $\begin{array}{l}\text { Branch network } \\
\text { New markets } \\
\text { Adoption of Technology }\end{array}$ \\
Product development strategy & $\begin{array}{l}\text { Creation of new products or modifying existing products and offering those } \\
\text { products to current or new markets }\end{array}$ & $\begin{array}{l}\text { Product modification } \\
\text { Product diversification }\end{array}$ \\
& $\begin{array}{l}\text { An application of the lowest cost of operation in an industry in order to gain } \\
\text { advantage over competitors }\end{array}$ & $\begin{array}{l}\text { Operation cost reduction } \\
\text { Efficiency of operations } \\
\text { Automation of operations }\end{array}$ \\
& & Change in membership \\
Crowth of SACCOs & Increase in membership, loans issued and return on equity & Change in loan portfolio \\
& & Return on equity \\
\hline
\end{tabular}

\section{Methodology}

This chapter discusses research design, location of the study, population of the study, sampling procedure and sample size, research instruments, data collection, validity, reliability, and data analysis.

\subsection{Research Design}

A research design is a blueprint for how the study will be carried out [11]. This study used descriptive survey research design. The design concerns itself with explorations, descriptions and explanations of opinions, attitudes, preferences and perceptions of the target population. Descriptive survey describes the events as they are, as they were, or as they will be. Abbott [2] further argues that descriptive survey is the most suitable design when a researcher wishes to explain events or opinions without manipulating variables. In this study, the researcher wished to explain the relationship between competitive strategies and growth of SACCOs in Tharaka Nithi County, without manipulating variables hence descriptive survey design was most appropriate.

\subsection{Location of the Study}

The location of the study was Tharaka Nithi, Kenya which is about $160 \mathrm{~km}$ north of Kenya's capital city, Nairobi. The County was adopted as the study area because it has the highest number of SACCOs compared to the neighboring counties [21].

\subsection{Population of the Study}

The population of the study was all the 52 managerial staff of all the SACCOs in Tharaka Nithi County, Kenya [21]. This is because firm's managerial staff is usually involved in crafting business level strategies which include market development, new product development, human resource, financial, legal and information and technology management strategies [17].

\subsection{Sampling Procedures and Sample Size}

Census survey technique was used. This means using the entire population as the sample [11]. This technique is suitable for small populations. If the population is not large, a census survey may provide better results than any sample survey [2]. A census reduces sampling error and provides data on all of the population's members [21]. The sample size for this study was the 52 managerial staff of the 10 SACCOs in Tharaka Nithi County, Kenya [21].

\subsection{Research Instruments}

Primary data was collected using structured questionnaires. Data collection schedule for membership, loans issued and return on equity was used to collect secondary data. Secondary data was gathered from SACCO annual financial reports. Questionnaires enable respondents to have freedom to express their views or opinions and also to make suggestions [51]. Questionnaires are also economical and save time. Where need be, structured face to face interview was used. The aim of the questionnaires was to capture responses for the study objectives and it covered the following sections: The first section covered demographics which included variables like the gender and number of years a SACCO has been in operation. The second section covered strategies employed by SACCOs to gain growth.

\subsection{Data Collection Procedure}

The researcher applied to Kenya's national commission for science, technology, and innovation for a research permit. The researcher distributed questionnaires to the management staff of the 10 SACCOs with the assistance of a research assistant, and they were collected two weeks later.

\subsection{Validity}

Validity is the extent to which research can be correctly interpreted and generalized to other population [52]. Validity is the extent to which a research instrument measures what it is designed to measure [52]. Kitagawa assert that validity refers to the accuracy and significance of inferences drawn from research findings [23]. It is concerned with the accuracy with which the data collected in the analysis reflects the study's variables. If the data correctly represents the variables, the inferences made from it would be correct and meaningful. Kitagawa [23] notes that validity is a matter of degree thus no data can be perfectly valid. Validity was ensured through 
use of experts who were the supervisors of the researcher.

\subsection{Reliability}

Reliability is the extent to which research results are consistent over time, over place and over methods [52]. It is a metric measuring how well a research instrument produces stable findings after several trials [48]. Reliability was determined by the test-re-test method. The researcher administered the instruments to a random sample of 16 managerial staff of 2 SACCOs in Meru County twice within a span of 14 days. The scores on the two sets of measures were then correlated to obtain estimated coefficient of reliability of the instruments and the items were modified and the process repeated until reliability index of at least .70 is obtained which is recommended in social research [48].

\subsection{Data Analysis}

Data analysis is the method of analyzing and deducing findings from data obtained in a survey or experiment [3]. It varies depending on the research's intent, the research's complexity, and the ease with which conclusions can be drawn [3]. After the instruments were administered, data collected was coded, edited, cleaned and the keyed in the computer for analysis. The data was analyzed using descriptive statistics such as frequency and percentages, as well as inferential statistics such as Chi-square to measure significance. The statistical package for social sciences (SPSS) version 21 was used to facilitate the analysis.

\subsection{Data Analysis Matrix}

Table 3. Data analysis Matrix.

\begin{tabular}{|c|c|c|c|}
\hline Research Hypothesis & Independent Variable & Dependent Variable & Statistics \\
\hline $\begin{array}{l}\mathrm{H}_{01} \text { There is no significant relationship between market development } \\
\text { strategy and growth of SACCOs in Tharaka Nithi County }\end{array}$ & $\begin{array}{l}\text { Market development } \\
\text { strategy }\end{array}$ & SACCO growth & $\begin{array}{l}\text { Frequencies, Chi-square, } \\
\text { percentages }\end{array}$ \\
\hline $\begin{array}{l}\mathrm{H}_{02} \text { There is no significant relationship between product development } \\
\text { strategy and growth of SACCOs in Tharaka Nithi County }\end{array}$ & $\begin{array}{l}\text { product development } \\
\text { strategy }\end{array}$ & SACCO growth & $\begin{array}{l}\text { Frequencies, Chi-square, } \\
\text { percentages }\end{array}$ \\
\hline $\begin{array}{l}\mathrm{H}_{03} \text { There is no significant relationship between cost leadership strategy } \\
\text { and growth of SACCOs in Tharaka Nithi County }\end{array}$ & cost leadership strategy & SACCO growth & $\begin{array}{l}\text { Frequencies Chi-square, } \\
\text { percentages }\end{array}$ \\
\hline
\end{tabular}

\section{Results and Discussions}

This chapter presents the research findings and discusses these results with reference to specific research objectives. The objectives of the study were to determine the effect of market development strategy on growth of SACCOs in Tharaka Nithi County, to establish the effect of product development strategy on growth of SACCOs in Tharaka Nithi County and to determine the effect of cost leadership strategy on growth of SACCOs in Tharaka Nithi County. The chapter begins by explaining the preliminary analysis.

\subsection{Preliminary Analysis}

The study sought to conduct preliminary analysis on the variables. The following analysis was conducted.

\subsubsection{Response Rate}

The respondents were given 52 questionnaires, and the researcher received 37 completed questionnaires back. The results obtained were as shown in table 4 .

Table 4. Response rate.

\begin{tabular}{lll}
\hline Category & Frequency & Percentage \\
\hline Questionnaires returned & 37 & 71.15 \\
Questionnaires not returned & 15 & 28.85 \\
Total & 52 & 100 \\
\hline
\end{tabular}

\subsubsection{Period of SACCO Operation}

The study sought to determine the period the SACCOs have been in operation. SACCOs exists for a long time without exiting the market if they normally gain profits, or operating at break -even point. The results about the length of operation of the SACCOs were represented in table 5 .

Table 5. Period of SACCO Operation.

\begin{tabular}{lll}
\hline & Frequency & Percent \\
\hline $5-10 \mathrm{yrs}$ & 3 & 8.1 \\
$11-15 \mathrm{yrs}$ & 4 & 10.8 \\
over 15yrs & 30 & 81.1 \\
Total & 37 & 100.0 \\
\hline
\end{tabular}

The results from table 5 indicated that majority $(81.1 \%)$ of the SACCOs existed for over 15 years. $10.8 \%$ of the SACCOs existed for a period between 11-15 years, while $8.1 \%$ of the SACCOs existed for a period between 5-10 years. This implies that there have emerged new SACCOs in the market for the last 5-10 years. This indicates that the SACCO movement in the county has been growing.

\subsubsection{Descriptive Statistics}

The study sought to determine the relevant descriptive statistics of the SACCO growth variables. Table 6 shows the mean, minimum, maximum, standard deviation and skewness values of each variable. The results were from 37 respondents who complied out of the 52 targeted staff. The results were represented in the table 6 .

Table 6 indicates that there has been an increasing membership level among the SACCOS with a minimum of 79,122 members and maximum of 94,183 members. The minimum Loan issued was ksh. 20,800,000 and the maximum was ksh. $29,000,000$. Return on equity has been on the rise with a minimum of $147.72 \%$ and maximum of $196.66 \%$. All the variables had a skewness of between -3 and 
+3. This implies that the data was normal and suitable for analysis.

Table 6. Descriptive Statistics.

\begin{tabular}{lllll}
\hline Variable & Range & Minimum & Maximum & Mean \\
\hline Membership & 15061 & 79122 & 94183 & 86756 \\
Reserves & $52.93 \mathrm{M}$ & $107 \mathrm{M}$ & $160 \mathrm{M}$ & $139.97 \mathrm{M}$ \\
Loan issued & $822 \mathrm{M}$ & $2080 \mathrm{M}$ & $2900 \mathrm{M}$ & -1.24 \\
EAT & $24.35 \mathrm{M}$ & $64.037 \mathrm{M}$ & $88.396 \mathrm{M}$ & -1.612 \\
Share capital & $58.52 \mathrm{M}$ & $154 \mathrm{M}$ & $212 \mathrm{M}$ & $73.782 \mathrm{M}$ \\
ROE & $49.1 \%$ & $147.72 \%$ & $196.82 \%$ & $180 \mathrm{M}$ \\
\hline
\end{tabular}

Key: $\mathrm{M}=$ millions

\subsection{Market Development Strategy}

The study also sought to determine the distribution and effect of market development strategy on growth of SACCOs in Tharaka - Nithi County. The results were presented in table 7

Table 7. Frequency Distribution (Market Development Strategy).

\begin{tabular}{|c|c|c|c|c|c|}
\hline Research item & Very great extent & Great extent & Moderate extent & Some extent & No extent \\
\hline Opening of new branches & $17(45.9 \%)$ & $10(27 \%)$ & $6(16.2 \%)$ & $3(8.1 \%)$ & $1(2.7 \%)$ \\
\hline Markets for existing products & $29(78.4 \%)$ & $1(2.7 \%)$ & $3(8.1 \%)$ & $2(5.4 \%)$ & $2(5.4 \%)$ \\
\hline Technology for service delivery & $17(45.9 \%)$ & $11(29.7 \%)$ & $0(0 \%)$ & $7(18.9 \%)$ & $2(5.4 \%)$ \\
\hline
\end{tabular}

From table 7 , it can be revealed that $45.9 \%, 27 \%$ and $16.2 \%$ technology for service delivery has been adopted to a very Very greatly agree (VGA), Greatly agree (GA) and Moderately agree (MA) respectively that opening of new branches strategy has been adopted by SACCOs. From the results only $8.1 \%$ shows that opening of new branches has been adopted to some extent. $2.7 \%$ indicates that the strategy has not been adopted. Larger portion shows that finding markets for existing products strategy has been adopted to great extent on Sacco's in Tharaka Nithi County with only $5.4 \%$ indicating that the strategy has not been adopted. $(45.9 \%)$ and $(29.7 \%)$ of the respondents agree that great extent and great extent respectively. 5.4\% of these respondents indicates that the strategy has been adopted to some extent.

\subsection{Product Development Strategy}

The study also sought to analyze the distribution of the product development strategies. These strategies included the modification of products and diversification of products. The results were presented in table 8 .

Table 8. Frequency Distribution (Product Development Strategy).

\begin{tabular}{|c|c|c|c|c|c|}
\hline Research item & Very great extent & Great extent & Moderate extent & Some extent & No extent \\
\hline Modification of products & $10(27 \%)$ & $16(43.2 \%)$ & $4(10.8 \%)$ & $3(8.1 \%)$ & $4(10.8 \%)$ \\
\hline Diversification of products & $13(35.1 \%)$ & $5(13.5 \%)$ & $12(32.4 \%)$ & $6(16.2 \%)$ & $1(2.7 \%)$ \\
\hline
\end{tabular}

From table 7 , it can be revealed that $27 \%$ agree that modification of Sacco products strategy has been adopted to a very great extent, $43.2 \%$ agree that the adoption is on great extent, $10.8 \%$ agree that the adoption is moderate, $8.1 \%$ agree that modification has been adopted to some extent while $10.8 \%$ agree that the modification of products has not been adopted. $35.1 \%$ of the respondents agree that diversification of products has been adopted to a very great extent, $13.5 \%$ agree that the adoption is to a great extent, $32.4 \%$ agree that the adoption is moderate, $16.2 \%$ agree that the adoption is of some extent while $2.7 \%$ agree that there is no adoption of diversification of products strategy.

\subsection{Cost Leadership Strategy}

The study analyzed the distribution and effect of the cost leadership strategy. The results were presented in Table 9.

Table 9. Frequency Distribution (Cost Leadership Strategy).

\begin{tabular}{|c|c|c|c|c|c|}
\hline Research item & Very great extent & Great extent & Moderate extent & Some extent & No extent \\
\hline Operation Cost reduction & $2(5.4 \%)$ & $1(2.7 \%)$ & $14(37.8 \%)$ & $11(29.7 \%)$ & $9(24.3 \%)$ \\
\hline Efficient operations & $4(10.8 \%)$ & $6(16.2 \%)$ & $2(5.4 \%)$ & $14(37.8 \%)$ & $11(29.7 \%)$ \\
\hline Automation of operations & $6(16.2 \%)$ & $8(21.6 \%)$ & $12(32.4 \%)$ & $7(18.9 \%)$ & $4(10.8 \%)$ \\
\hline
\end{tabular}

From table 9, it can be revealed that only a small portion of $5.4 \%$ agree that cost reduction strategy has been adopted with a very great extent while $2.7 \%$ agree that the adoption is of great extent. A large portion of $37.8 \%, 29.7 \%$ and $24.3 \%$ indicates a moderate extent, some extent and No extent respectively that cost reduction strategy has been adopted in SACCOs in Tharaka Nithi County. 10.8\%, 16.2\% and 5.4\% to a very great extent, great extent and moderate extent 
indicates that SACCO operations are efficient. A larger portion $37.8 \%$ and $29.7 \%$ agree to some extent and no extent respectively, that the SACCO operations are efficient. $16.2 \%$, $21.6 \%$ and $32.4 \%$ agree that SACCO operations are to a very great extent, great and moderate extent respectively automated. $18.9 \%$ and $10.8 \%$ indicates that automation of operations of SACCOs in Tharaka Nithi County is to some extent and no extent respectively.

\subsection{Effect of Market Development Strategy on Growth of SACCOs}

The market development strategy was indicated by finding new markets for existing products, adopting technology for service delivery and opening of new branches. The growth of SACCOs was indicated by membership, loan issued and return on equity. The study begun by determining the effect of opening of new branches against membership, loans issued and ROE, determining effect of finding new markets for existing products against membership, loan issued and ROE and finally determining the extent of adopting technology for service delivery against membership, loan issued and return on equity. The results were presented in table 10.

Table 10. Chi-square Test on Market Development Strategy against Growth of SACCOs.

\begin{tabular}{|c|c|c|c|}
\hline Variables & Pearson chi-square value & d.f & Asymp. Sig. (2-sided) \\
\hline Opening new branches against membership & $100.484^{\mathrm{a}}$ & 12 & 0.002 \\
\hline Opening new branches against loans issued & $60.021^{\mathrm{a}}$ & 16 & 0.000 \\
\hline Opening new branches against ROE & $51.098^{\mathrm{a}}$ & 16 & 0.006 \\
\hline Finding new markets for existing products against membership & $25.136^{\mathrm{a}}$ & 12 & 0.014 \\
\hline Finding new markets for existing products against loans issued & $59.994^{\mathrm{a}}$ & 16 & 0.010 \\
\hline Finding new market for existing products against ROE & $35.219^{\mathrm{a}}$ & 16 & 0.004 \\
\hline Adoption of technology against loan issued & $41.489^{\mathrm{a}}$ & 12 & 0.000 \\
\hline Adoption of technology against ROE & $69.495^{\mathrm{a}}$ & 12 & 0.024 \\
\hline $\mathrm{N}$ of Valid Cases & 37 & & \\
\hline
\end{tabular}

The chi-square test from table 10 shows a p-value of 0.002 $<0.05$ indicating that there exists a significant relationship between opening of new branches and membership as an indicator of growth of SACCOs. A p- value of 0.000 implied that there exists a significant relationship between opening of new branches and loans issued. Also a p-value of 0.006 implied existence of a significant relationship between opening of new branches and return on equity. This indicated that opening of new branches significantly influences the growth of SACCOs at 5\% significant level.

A chi-square test on finding new markets for existing products against membership shows a $\mathrm{p}$ value of $0.014<$ 0.05 indicating that there exists a significant relationship between finding new markets for existing products and membership. A p-value of 0.010 indicated existence of a significant relationship between finding new markets for existing products and loans issued. Also, a p-value of 0.004 implied existence of a significant relationship between finding new markets for existing products and return on equity. This implied that increase in new markets for existing products significantly influences growth of SACCOs at $5 \%$ significance level.

A p-value of 0.000 of the chi-square test on adoption of technology and membership implied that there exists a significant relationship between the two variables. A p-value of 0.000 of the chi-square test on the relationship between technology adoption and loans issued implied existence of a significant relationship between the variables. A chi-square test on adopting of technology against return on equity shows a $\mathrm{p}$ value of $0.024<0.05$ indicating that there exists a significant relationship between adopting of technology and growth of SACCOs in terms of return on equity. This implied that increase technology adoption significantly influences growth of SACCOs at 5\% significance level. Generally, given that all the above $\mathrm{p}$-values all less than 0.05 , it is evident that there is a significant relationship between market development strategy and growth of SACCOs. These findings are supported by a study by Kaara [18] which found that in an attempt to enhance growth, SACCOs in Nyeri responded to challenges in the volatile environment by adopting market development strategies. These findings are further reinforced by the findings of Mbithi's study that market development strategies increase sales volume and turnover hence growth of SACCOs [28].

\subsection{Effect of Product Development Strategy on Growth of SACCOS}

The study sought to determine the relationship between product development strategy and growth of SACCOs in Tharaka Nithi County. The Product development strategy was indicted by the level of modification of products and diversification of products by SACCOs. The growth of SACCOs was indicated by membership, loan issued and return on equity. The study begun by determining the effect of product modification against membership, loan issued and ROE and determining the effect of diversification of products against membership, loan issued and return on equity. The results were presented in table 11 . 
Table 11. Chi-square on Product Development Strategy against Growth of SACCOs.

\begin{tabular}{llll}
\hline Variables & Pearson chi - square value & Df & Asymp. Sig. (2-sided) \\
\hline Modification of products against membership & $47.055^{\mathrm{a}}$ & 12 & 0.000 \\
Modification of product against loan issued & $122.306^{\mathrm{a}}$ & 16 & 0.000 \\
Modification of products against ROE & $61.416^{\mathrm{a}}$ & 16 & 0.002 \\
Diversification of products against membership & $40.510^{\mathrm{a}}$ & 12 & 0.000 \\
Diversification of products against loans issued & $52.353^{\mathrm{a}}$ & 16 & 0.001 \\
Diversification of products against ROE & $95.034^{\mathrm{a}}$ & 16 & 0.032 \\
N of Valid Cases & 37 & & \\
\hline
\end{tabular}

The chi-square test from table 11 shows a $\mathrm{p}$ value of 0.000 $<0.05$ indicating that there exists a significant relationship between modification of products and membership in SACCOs in Tharaka Nithi county at 5\% significance level. A p-value of 0.000 on the chi-square test between modification of products and loan issues implied a significant relationship between modification of products and loans issued. A - - value of 0.002 also implies that there exists a significant relationship between modification of products and ROE. This implied that increased product modification significantly leads to growth of SACCOs in Tharaka Nithi County.

A p-value of $0.000<0.05$ of the chi-square test between product diversification against membership implied a significant relationship between the variables. Also, a p-value of $0.001<0.005$ implied that there exists a significant relationship between product diversification strategy and loans issued. A chi-square test on product diversification against return on equity shows a $\mathrm{p}$ value of $0.032<0.05$ indicating that there exists a significant relationship between diversification of products and ROE at 5\% significance level. Generally, given the above p-values of less than 0.05 , it is evident that product development strategy significantly influences growth of SACCOs. These findings are in agreement with a study by Uluma [50] which found that
Sacco's survival and growth depend on the kind of products they offer and how differently they offer them to the members compared to other similar providers of the product. The findings are also supported by the findings of a study by Olunja [40] which found that market development strategy is critical for survival and growth of SACCO in Dagoret district.

\subsection{Effect of Cost Leadership Strategy on Growth of SACCOS}

The study sought to determine the effect of cost leadership strategy on growth of SACCOs in Tharaka Nithi County. The cost leadership strategy was indicated by the level of operation cost reduction, efficiency of operations and automation of operations. The growth of SACCOs was indicated by membership; loan issued and returns on equity. The study begun by determining the effect of operation cost reduction strategy against membership, loans issued and return on equity, then determining the effect of efficiency of operations against membership, loans issued and return on equity, then later determining the effect of automation of operations against membership, loan issued and return on equity. The results were presented in table 12 .

Table 12. Chi-square on Cost Leadership Strategy against Growth of SACCOs.

\begin{tabular}{llll}
\hline Variable & Pearson chi - square value & Df & Asymp. Sig. (2-sided) \\
\hline Adoption of cost reduction strategy on membership & $54.411^{\mathrm{a}}$ & 12 & 0.001 \\
Adoption of cost reduction strategy on loans issued & $65.307^{\mathrm{a}}$ & 16 & 0.000 \\
Adoption of cost reduction strategy against ROE & $70.037^{\mathrm{a}}$ & 16 & 0.005 \\
Efficiency operations against membership & $54.666^{\mathrm{a}}$ & 12 & 0.013 \\
Efficiency of operations against loans issued & $83.275^{\mathrm{a}}$ & 16 & 0.017 \\
Efficiency of operations against ROE & $62.317^{\mathrm{a}}$ & 16 & 0.001 \\
Automation of operation against membership & $80.079^{\mathrm{a}}$ & 16 & 0.042 \\
Automation of operations against loans issued & $92.122^{\mathrm{a}}$ & 16 & 0.000 \\
Automation of operations against ROE & $78.307^{\mathrm{a}}$ & 16 & 0.000 \\
$\mathrm{~N}$ of Valid Cases & 37 & & \\
\hline
\end{tabular}

The results on chi-square test in table 12 shows a $\mathrm{p}$ value of $0.001<0.05$ indicating that there exists a significant relationship between cost reduction strategy and membership levels at $5 \%$ significance level. A p-value of 0.000 implies that there is a significant relationship between adoption of cost reduction strategy and loans issued, while a p-value of 0.005 also indicates existence of significant relationship between cost reduction strategy and ROE. This implied that cost reduction strategy leads to growth of SACCOs in Tharaka Nithi County.

A p-value of 0.013 indicates a significant relationship between efficiency of operations and level of membership. A chi-square test shows a $\mathrm{p}$ value of $0.017<0.05$ indicating that there exists a significant relationship between efficiency 
of operations and loan issued at 5\% significance level. Also, a $p$-value of 0.001 indicates that there exists a significant relationship between efficiency of operations and ROE. This implied that efficiency of operations significantly leads to growth of SACCOs in Tharaka Nithi County.

A chi-square test shows a $p$ value of $0.042<0.05$ indicating that there exists a significant relationship between automation of operations and membership at 5\% significance level. P-values of 0.000 indicate that there exists a significant relationship between automation of operations and loans issued. P-values of 0.000 indicate that there exists a significant relationship between automation of operations and ROE. This implied that automation of operations significantly leads to growth of SACCOs in Tharaka Nithi County. Generally, given the above p-values all of less than 0.05 , it is evident that cost leadership strategy has a significant effect on growth of SACCOs. These findings concur with the findings of a study by Olunja [40] which revealed that to increase their growth and financial levels, SACCOs should apply technology in their day to day activities and hence reduce costs by providing reliable, intuitive online self-service options to their customers. However, the findings of Habimana's [13] study were that there was no relationship between cost leadership strategy and growth of commercial banks in Rwanda because some banks under study had low level of cost and at the same time low level growth while others had low level costs and a high level growth.

\section{Summary, Conclusions and Recommendations}

This chapter summarizes the study's results in relation to the objectives. It also includes conclusions, recommendations and suggestions for further research.

\subsection{Summary of Findings}

The study aimed at determining the effect of competitive strategies on growth of savings and credit cooperative societies in Tharaka -Nithi County, Kenya. The specific objectives of the study were to determine the effect of market development strategy on growth of SACCOs in Tharaka Nithi County, to establish the effect of product development strategy on growth of SACCOs in Tharaka Nithi County and to determine the effect of cost leadership strategy on growth of SACCOs in Tharaka Nithi County.

The first objective was to determine the effect of market development strategy on growth of SACCOs in Tharaka Nithi County. The market development strategy was indicated by opening of new branches, finding new markets for existing products and adopting technology for service delivery. The growth of SACCOs was depicted by membership levels, loans issued and return on equity. The results indicated that opening new branches had a significant effect on the membership levels, loans issued and ROE with p-values of less than 0.05 at $5 \%$ significance level. This implies that increase in new branches leads to increase in number of new members, loans issued and ROE. The study also found that finding new markets for existing products had a significant effect on the levels of membership, loans issued and ROE with p-values less than 0.05 at $5 \%$ significance level. Also, increase in technology adoption had significantly impacted on membership, loans issued and return on equity with p-values less than 0.005 at $5 \%$ significance level. These results implied that the market development strategy had a significant effect to the growth of SACCOs in Tharaka Nithi County.

The second objective was to establish the effect of product development strategy on growth of SACCOs in Tharaka Nithi County. The product development strategy was indicated by modification of products and diversification in products while the growth of SACCOs was represented by membership levels, loans issued and return on equity. The results showed that there existed a significant relationship between modification of products and membership, loans issued and ROE with p-values less than 0.05 at 5\% significance level. The results also showed that diversification of products significantly impacted on membership, loans issued and return on equity with $p$-values less than 0.05 at $5 \%$ significance level. From the findings of the study, it emerged that product development strategy significantly impacted on growth of SACCOs in Tharaka Nithi County at 5\% significance level.

The third objective of the study was to determine the effect of cost leadership strategy on growth of SACCOs in Tharaka Nithi County. Cost leadership strategy was indicated by the level of operation cost reduction, automation of operations and efficiency of operations while the growth of SACCOs was depicted by membership levels, loans issued and returns on equity. The results also showed that adoption of cost reduction strategy, efficient operations and automated operations had a significant effect on membership, loans issued and returns on equity with p-values less than 0.005 at $5 \%$ significance level. This implied that cost leadership strategy had a significant effect on the growth of SACCOs in Tharaka Nithi County at 5\% significance level.

\subsection{Conclusions}

From the findings of the study, it can be concluded that competitive strategies namely; market development, product development and cost leadership strategies significantly influenced growth of SACCOs. This shows that SACCOs are endeavoring to apply these competitive strategies so as to attain sustainable competitive advantage and enhance their growth. In this study, all the variables subjected to chi-square produced p-value of less than 0.05 , which implied that the null hypotheses developed were rejected and consequently the alternative hypotheses accepted as: There is significant relationship between market development strategy and growth of SACCOs in Tharaka Nithi County, there is significant relationship between product development strategy and growth of SACCOs in Tharaka Nithi County and there is significant relationship between cost leadership strategy and growth of 
SACCOs in Tharaka Nithi County.

\subsection{Recommendations}

The following recommendations were made based on the study's results.

1. SACCOs should sustain market development strategies to enhance growth. They should strive to acquire new customers by offering their current products to market segments which were not their previous customers or move into new geographical segments. SACCOs should commit more resources towards enhancement of this competitive strategy.

2. SACCOs need to enhance their product development strategies to foster growth. This can be achieved through modification of existing products or creation of new products that can be marketed to current customers.

3. SACCOs should sustain cost leadership strategies through economies of scale, adopting cost cutting technology, reduction of overhead and administrative expenses to enhance growth. They should ensure they have the lowest cost of operation in the industry relative to that of competitors in order to gain advantage over them and achieve growth. SACCOs should identify areas where to implement cost reduction like production, marketing and research.

\subsection{Suggestions for Further Research}

The following areas for further analysis are suggested based on the study's results.

1. Challenges facing SACCOs in the implementation of the competitive strategies.

2. Effect of market sensitization strategies on growth of SACCOs.

\section{Abbreviations and Acronyms}

$\begin{array}{ll}\text { ATM } & \text { Automatic teller machine. } \\ \text { GDP } & \begin{array}{l}\text { Gross domestic product. } \\ \text { Information communication technology. }\end{array} \\ \text { KCT } & \begin{array}{l}\text { Kenya union of savings and credit. } \\ \text { cooperatives. }\end{array} \\ \text { MCSDM } & \begin{array}{l}\text { Ministry of cooperative society development } \\ \text { and marketing. }\end{array} \\ \text { NDP } & \text { New product development. } \\ \text { R\&D } & \text { Research and design. } \\ \text { RBV } & \text { Resource based view. } \\ \text { SACCOs } & \text { Savings and credit cooperative societies. } \\ \text { SPSS } & \text { Statistical package for social Sciences. } \\ \text { WOCCU } & \text { World council of credit unions. }\end{array}$

\section{Ethical Considerations}

It was appropriate to have the research approved by the University in order to validate the study and provide evidence that that it was carried out according to established research standards and practices. The respondents were told that the information they provided would not be exchanged with someone who was not a direct participant in the research and that it would only be used for academic purposes. Informed consent was obtained from research participants in order to gain their interest and belief in the study's goals, which were solely academic in nature.

\section{References}

[1] Abraham, S., 2011. Crafting good strategy is hard work and involves tough choices. Strategy \& Leadership, 40 (1).

[2] Abbott, M., 2013. Understanding and applying research design. Hoboken, N. J.: John Wiley \& Sons, Inc.

[3] Agresti, A., 2014. Categorical Data Analysis. Hoboken: Wiley.

[4] Barney, J., 2016. Text and metatext in the resource-based view. Human Resource Management Journal, 26 (4), pp. 369-378.

[5] Birchall, J., (2009). Cooperatives and Millennium Development goals. Geneva, Switzerland

[6] Bowker, L., 2016. The Embedded Records Manager: A Pilot Study Emphasizing the Importance of Community as a Key to Success. Proceedings of the Annual Conference of CAIS / Actes du congrès annuel de l'ACSI.

[7] Czakon, W., 2013. Handbook of research on competitive strategy.M@n@gement,16 (1),p.106.

[8] Dahan, E., (2007). New Product Development: Essential Marketing Knowledge and Practice. Colombus Ohio, United States: Mc Grahill publishers.

[9] Ding, D., 2005. Market Orientation, Competitive Strategy and Firm Performance. Journal of Global Marketing, 18 (3-4), pp. 115-142.

[10] Dogarawa, A., 2013. Manpower Challenge of Non-Interest Banking Framework in Nigeria. Journal of Islamic Economics, Banking and Finance, 9 (1), pp. 9-20.

[11] Grand, S., 2012. Mapping design research. Basel: Birkhauser.

[12] Gumusluoglu, L., 2016. Fit Among Business Strategy, Strategy Formality, and Dynamic Capability Development in New Product Development. European Management Review, 13 (2), pp. 107-123.

[13] Habimana, H., (2012). Cost Leadership Strategy and Competitive advantage in commercial banks in Rwanda. Kigari, Rwanda.

[14] Hamid, B., (2014). Effects of Cost Leadership Strategy on Future Performance of accepted Companies in Tehran stock exchange. Research journal of finance and accounting, 5 (7).

[15] Hansen, Z., 2011. Global product development: the impact on the product development process and how companies deal with it. International Journal of Product Development, 15 (4), p. 205.

[16] Harris, E., 2014. Customer service. Harlow, Essex: Pearson. 
[17] Hoon, C., 2015. The Emergence of Strategy: Capturing the Dynamics of Strategy Formulation Across Levels. Academy of Management Proceedings, 2015 (1), p. 18167.

[18] Kaara, F., (2015). Market and Product Development Strategies used in Response to Environmental Changes faced by SACCOs in Nyeri County, Kenya: A case of CIC insurance group LTD. International journal of economics, commerce and management, 3 (12).

[19] Kachaner, N., 2011. Innovating low-cost business models. Strategy \& Leadership, 39 (2), pp. 43-48.

[20] Kefie, T., (2015). Savings and Credit Cooperatives in Ethiopia: Development Challenges and Proposed Intervention. International journal of cooperative studies, 4 (1), 1-8.

[21] Kenya Ministry of Co-operative Development \& Marketing. (2016).

[22] Kipkosgei, B., (2014). Effects of New Product Development on Customer Attraction by SACCOs in Baringo County, Kenya. Jomo Kenyatta University, Nairobi, Kenya.

[23] Kitagawa, T., 2015. A Test for Instrument Validity. Econometrica, 83 (5), pp. 2043-2063.

[24] Liddell Hart, C., 2016. Strategy. San Francisco: Tannenberg Publishing.

[25] Magali, J., 2014. Effectiveness of Loan Portfolio Management in Rural SACCOS: Evidence from Tanzania. Business and Economic Research, 4 (1), p. 301.

[26] McCann, J., 2012. Emerging market strategy development and implementation. J. for International Business and Entrepreneurship Development, 6 (3/4), p. 244.

[27] McDonald, M., 2011. Pocket guide to selling products and services. London: Routledge.

[28] Mbithi, B., (2015). Effect of Market Development sStrategy on Performance in sugar Industry in Kenya. International journal of academic research in business and social sciences, 5 (12).

[29] Mosiria, M. (2012). Relationship between Internal Growth Strategies and Performance. Nairobi, Kenya.

[30] Mumanyi, A., (2014). Challenges and Opportunities facing SACCOs in the current Devolved system of Government of Kenya: A case of Mombasa County. International journal of social sciences and entrepreneurship, 1 (9), 288-314.

[31] Murunga, A., (2013). Role of SACCOs in enhancing Insurance Market Penetration in Kenya: A case of CIC insurance group LTD. Nairobi Kenya.

[32] Mutunga, L., (2014). Generic Strategies Employed by Food and Beverage Firms in Kenya. Nairobi, Kenya.

[33] Murithi, M., (2014). Factors Influencing start-ups, Growth and Survival of small and Medium Manufacturing Industries in Kenya. Nairobi, Kenya.

[34] Mwaura, S., (2013). Competitive Strategies Adopted by Private Universities in Kenya. Nairobi, Kenya.

[35] Ndungo, J., 2016. Effect of Credit Access Function on Financial Performance of SACCOs in Kenya. International Journal of Finance and Accounting, 1 (2), p. 35.
[36] Ngigi, P., (2014). Influence of Competitive Generic Strategies on Customer base in Deposit taking Microfinance Institutions in Nairobi County. International journal of business and commerce, 3 (12).

[37] Ngugi, F., (2015). Factors Affecting Growth of SACCOs within the Agricultural Sector in Kenya: A case of Meru farmers SACCO. Global journal of commerce and management, 4 (1), 34-45.

[38] Nyamwea, I., (2015). Assessment of the Effect of Cost Leadership strategy on the Performance of Liquefied Petroleum Gas Companies in Eldoret town, Uasin Gishu County, Kenya. International journal of business and management invention, 4 (4).

[39] Okibo, B., 2013. The Role of Corporate Strategy On Compliance with Government Regulations Among SACCOs in Kenya. Journal of Research in Marketing, 1 (3), p. 79.

[40] Olunja, E., (2013). Determinants of Growth of Rotating savings and credit Associations in Kiserian. Nairobi, Kenya.

[41] Penrose, E., (1959). The Theory of the Growth of the firm. California, United states: Willy Publishers.

[42] Pearce, J., \& Robinson (2009). Strategic Management: Formulation, Implementation and Control. McGraw, Newyork: Hill publishers.

[43] Parthasarthy, R., (2007). Foundations of Strategic Management. Boston, United States: Mifflin publishers.

[44] Rahman, R., 2014. Types of Fraud among Islamic Banks in Malaysia. International Journal of Trade, Economics and Finance, 5 (2), pp. 176-179.

[45] Ruttoh, K., (2015). Factors Influencing Growth of Cooperative Societies in Nandi Central District, Nandi County, Kenya. Nandi, Kenya

[46] Sinha, S., 2010. Disclosure and Financial Performance: A Cross Sectional Study of Microfinance Institutions of India. Review of Professional Management- A Journal of New Delhi Institute of Management, 8 (1), p. 20.

[47] S., M., B., K., E., K., J., R., C., S. and W. K, T., 2014. Determinants of Net Savings Deposits held in Savings and Credit Cooperatives (SACCOs) in Uganda. Journal of Economics and International Finance, 6 (4), pp. 69-79.

[48] Taherdoost, H., 2016. Validity and Reliability of the Research Instrument; How to Test the Validation of a Questionnaire/Survey in a Research. SSRN Electronic Journal.

[49] Tumwine, F., (2015). SACCOs'Services'terms and Members' Economic Development in Rwanda: A case of Zigama SACCO LTD. Kigari, Rwanda.

[50] Uluma, U., (2013). Determinants of Growth of Savings and Credit Co-operatives in Kenya. Wernerfelt, B. (1984.). A resource based View of the Firm. Strategic Management Journal, 5, 171-180.

[51] Wedderburn, C., 2011. Questionnaires, questionnaires. BMJ, p. d3124.

[52] White, T., 2013. Research methods. Belmont, CA: Wadsworth, Cengage Learning. 
[53] World Council of Credit unions. (2012). Statistical report. Washington, united states.

[54] Wikund, J., Davidsson, P., \& Delma, F. (2006). Entrepreneurship and Growth of Firms. Cheltelham, Elgar.

[55] Yasin, N., 2014. Statutory obligations for banks to comply with the anti-money laundering legislation in Malaysia: Lessons from the United Kingdom. Journal of Banking Regulation, 16 (4), pp. 326-344.

[56] Zott, C., 2007. The fit between product market strategy and business model: implications for firm performance. Strategic Management Journal, 29 (1), pp. 1-26. 